\title{
PENERAPAN PENDEKATAN SAINTIFIK UNTUK MENINGKATKAN HASIL BELAJAR PESERTA DIDIK KELAS VIII.D SMPN 11 KOTA BENGKULU
}

\author{
Yetti Widiarti \\ SMPN 11 Kota Bengkulu \\ yettismp11@gmail.com
}

\begin{abstract}
Abstrak
Penelitian ini bertujuan untuk menerapan pendekatan saintifik untuk meningkatkan hasil belajar peserta didik kelas VIII.D SMPN 11 Kota Bengkulu. Subyek penelitian adalah peserta didik/i kelas VIII.D SMPN 11 Kota Bengkulu tahun ajaran 2018/2019 yang berjumlah 31 peserta didik. Penelitian ini merupakan penelitian tindakan kelas dengan tahapan perencanaan, pelaksanaan tindakan, observasi, refleksi dan dilaksanakan dalam 2 siklus. Siklus I dilaksanakan sebanyak empat kali pertemuan yaitu pada tanggal 14 - 25 Januari 2019. Siklus II dilaksanakan sebanyak tiga kali pertemuan yaitu pada tanggal 28 Januari s.d 8 Februari 2019. Rata - rata hasil belajar peserta didik siklus I adalah 73 dan siklus II adalah 79. Dengan ketuntasan klasikal peserta didik pada siklus I adalah $61 \%$ dan pada siklus II sebesar $77 \%$. Dari hasil tersebut maka dapat disimpulkan bahwa pendekatan saintifik merupakan kegiatan pembelajaran yang dapat meningkatkan hasil belajar peserta didik terutama pada materi Pythagoras, sehingga sangat disarankan dalam kurikulum 2013.
\end{abstract}

Kata kunci: hasil belajar, pendekatan saintifik

\section{Abstract}

This study aims to apply a scientific approach to improve student learning outcomes in class VIII.D SMPN 11 Bengkulu City. The research subjects were students of class VIII.D SMPN 11 Bengkulu City in 2018/2019 school year with a total of 31 students. This research is a classroom action research with the stages of Planning $\rightarrow$ Implementation of actions $\rightarrow$ Observation $\rightarrow$ Reflection and carried out in 2 cycles. Cycle I held 4 meetings, namely on January 14-25, 2019. Cycle II held 3 meetings, namely on January 28 to February 8, 2019. The average learning outcomes of students in cycle I were 73 and cycle II was 79. With classical completeness of students in the first cycle was $61 \%$ and in the second cycle was $77 \%$. According to these results, it can be said that the scientific approach is a learning activity that can improve student learning outcomes, especially on Pythagorean material, so it is highly recommended in the 2013 curriculum.

Keywords: learning outcomes, scientific approach

\section{PENDAHULUAN}

Kurikulum

$2013(\mathrm{~K}-13)$ adalah kurikulum yang berlaku dalam Sistem Pendidikan Indonesia. Kurikulum ini mengisyaratkan pentingnya sistem penilaian yang mengacu pada tiga aspek penting yakni, knowledge, skill and attitude. Oleh sebab itu setiap sekolah harus siap dalam menghadapi dan menyiapkan segala sesuatunya untuk mewujudkan tujuan pendidikan yang terdapat di kurikulum 2013.

Dalam Lampiran Peraturan Menteri Pendidikan dan Kebudayaan Nomor 22 Tahun 2016 tentang Standar Proses
Pendidikan Dasar dan Menengah dinyatakan bahwa: Proses Pembelajaran pada satuan pendidikan diselenggarakan secara interaktif, inspiratif, menyenangkan, menantang, memotivasi pesertadidik untuk berpartisipasi aktif, serta memberikan ruang yang cukup bagi prakarsa, kreativitas, dan kemandirian sesuai dengan bakat, minat, dan perkembangan fisik serta psikologis peserta didik. Untuk itu setiap satuan pendidikan melakukan perencanaan pembelajaran, pelaksanaan proses pembelajaran serta penilaian proses pembelajaran untuk meningkatkan efisiensi 
dan efektivitas ketercapaian kompetensi lulusan.

Lebih lanjut dalam Lampiran Permendikbud tersebut disebutkan sejumlah prinsip pembelajaran, antara lain bahwa proses pembelajaran bergeser dari peserta didik diberi tahu menuju peserta didik mencari tahu, dari guru sebagai satusatunya sumber belajar menjadi belajar berbasis aneka sumber belajar, dan dari pendekatan tekstual menuju proses sebagai penguatan penggunaan pendekatan ilmiah atau saintifik.

Salah satu masalah yang dihadapi guru matematika SMPN 11 Kota Bengkulu adalah kurang aktifnya peserta didik dalam kegiatan pembelajaran. Kurang dalam kegiatan bertanya, dan hanya mengandalakan peserta didik yang pintar saja pada saat menyelesaikan tugas kelompok. Hal tersebut menyebabkan hasil belajar peserta didik kurang terutama dalam materi teorema Pythagoras. Kebanyakan peserta didik mengalami kesulitan dalam memahami hubungan sisi miring (hipotenusa) dengan kedua sisi siku-siku, sehingga masih banyak peserta didik yang hanya menghapal rumus Teorema Pythagoras yang diberikan.

Dalam mengatasi permasalahan diatas, guru hendaknya melakukan usaha dimulai dengan pembenahan proses pembelajaran yang dilakukan guru yaitu dengan menerapkan suatu pendekatan yang dapat meningkatkan kemampuan dan hasil belajar peserta didik. Salah satu pendekatannya yaitu dengan pendekatan Saintifik.

Pendekatan saintifik merupakan salah satu pendekatan ilmiah yang disarankan dalam pelaksanaan kurikulum 2013 di sekolah. Kemendikbud (2013) memberikan konsepsi tersendiri bahwa pendekatan ilmiah (scientific approach) dalam pembelajaran didalamnya mencakup komponen: mengamati, menanya, mencoba, mengolah, menyajikan, menyimpulkan, dan mencipta. Komponen-komponen tersebut seyogyanya dapat dimunculkan dalam setiap praktik pembelajaran, tetapi bukanlah sebuah siklus pembelajaran. (Waseso, 2018).

Waseso (2018) juga menjelaskan komponen dari pendekatan saintifik yaitu:
(1) Mengamati; Metode mengamati mengutamakan kebermaknaan proses pembelajaran (meaningfull learning). Metode ini memiliki keunggulan tertentu, seperti menyajikan media obyek secara nyata, peserta didik senang dan tertantang, dan mudah pelaksanaannya. Hasil dari kegiatan ini adalah peserta didik dapat mengidentifikasi masalah. (2) Menanya; Pada saat guru bertanya, pada saat itu pula dia membimbing atau memandu peserta didiknya belajar dengan baik. Ketika guru menjawab pertanyaan peserta didiknya, ketika itu pula dia mendorong asuhannya itu untuk menjadi penyimak dan pembelajar yang baik. Hasil dari kegiatan ini adalah peserta didik dapat merumuskan masalah / hipotesis. (3) Menalar; Penalaran adalah proses berfikir yang logis dan sistematis atas fakta-kata empiris yang dapat diobservasi untuk memperoleh simpulan berupa pengetahuan. (4) Mencoba; Untuk memperoleh hasil belajar yang nyata atau otentik, peserta didik harus mencoba atau melakukan percobaan. Dengan mencoba, diharapkan pada kegiatan ini adalah peserta didik dapat menguji hipotesis. Selanjunya peserta didik dapat menyimpulkan hasil pemecahan masalah yang telah mereka lakukan.

Keunggulan pendekatan saintifik dalam proses pembelajaran adalah pembelajaran berpusat pada peserta didik sehingga memungkinkan peserta didik untuk lebih aktif dalam pembelajaran. Pembelajaran dengan pendekatan saintifik memberikan kesempatan kepada peserta didik untuk melakukan belajar dalam konsteks, menciptakan aktivitas belajar kelompok, mengarahkan peserta didik untuk dapat mengkonstruktruksi pengetahuan, guru dan peserta didik bekerja sama untuk mencari solusi terhadap suatu permasalahan, serta guru perlu memberi arah yang konsisten agar peserta didik dapat memperoleh pengalaman belajar yang bermakna.

Tujuan pembelajaran dengan metode saintifik adalah sebagai berikut: a. Meningkatkan kemampuan intelektual, khususnya kemampuan berpikir tingkat tinggi peserta didik; b. Membentuk 
kemampuan peserta didik dalam menyelesaikan suatu masalah secara sistematik; c. Memperoleh hasil belajar yang tinggi; d. Melatih peserta didik dalam mengomunikasikan ide-ide, khususnya dalam menulis karya ilmiah; serta e. Mengembangkan karakter peserta didik. (Kemendikbud, 2016 : 31). Kelebihan metode saintifik dibandingkan dengan metode ceramah adalah bahwa metode saintifik dapat mengembangkan kemampuan berfikir kritis dan inovatif, bekerjasama/kolaborasi, berkomunikasi, kreativitas. Hal yang demikian tidak ditemukan pada metode ceramah.

Berdasarkan uraian di atas, diharapkan pendekatan saintifik dapat membuat peserta didik menjadi lebih aktif dan dapat meningkatkan hasil belajar peserta didik pada materi Pythagoras. Oleh karena itu, peneliti tertarik untuk melakukan penelitian yang berjudul "Penerapan Pendekatan Saintifik untuk Meningkatkan Hasil Belajar Peserta didik Kelas VIII.D SMPN 11 Kota Bengkulu". Adapun tujuan penelitian ini adalah untuk meningkatkan hasil belajar materi pythagoras dengan menerapkan pendekatan saintifik peserta didik kelas VIII.D SMPN 11 kota bengkulu tahun pelajaran 2018/2019.

\section{METODE}

Jenis penelitian ini merupakan penelitian tindakan kelas. Penelitian tindakan kelas adalah penelitian yang dilakukan oleh pendidik untuk memperbaiki kinerjanya menyangkut kualitas proses pembelajaran. Prosedur penelitian tindakan kelas dilakukan dengan 4 tahap yaitu tahap perencanaan (planning), pelaksanaan tindakan (acting), Observasi / Pengamatan
(Observing), dan Refleksi (Reflecting). (Saur Tampubolon, 2013 : 19-20).

Subjek penelitian ini adalah peserta didik kelas VIII.D SMPN 11 Kota Bengkulu tahun ajaran 2018/2019 yang berjumlah 31 orang. Instrumen dalam penelitian ini adalah lembar tes. Dari hasil tes tersebut akan dihitung nilai rata - rata peserta didik dan ketuntasan klasikal kelas.

Adapun kriteria keberhasilan dalam penelitian ini adalah apabila nilai rata - rata peserta didik sebesar 75, yaitu sesuai dengan KKM matematika yang ditetapkan sekolah dan ketuntasan klasikal yaitu jumlah peserta didik yang tuntas mencapai nilai KKM sebesar $75 \%$.

\section{HASIL PENELITIAN DAN PEMBAHASAN}

Pembelajaran dimulai dengan, guru membagikan kelompok yang dibentuk berdasarkan nilai ulangan harian pada pokok bahasan sebelumnya dan pertimbangan guru.

Siklus I dilaksanakan sebanyak 4 kali pertemuan yaitu pada tanggal $14-25$ Januari 2019. Setelah menjelaskan tujuan pemebelajaran, guru meminta peserta didik duduk di kelompoknya masing - masing, kemudian guru melaksanakan pembelajaran sesuai dengan pendekatan saintifik. Guru meminta mengamati masalah kontekstual yang berkaitan dengan teorema Pythagoras. Kemudian peserta didik diminta melaksanakan tahap - tahap saintifik, yaitu mengamati, menanya, mencoba, menalar, dan mengkomunikasikan.

Secara umum pembelajaran dengan metode saintifik dilakukan melalui sejumlah langkah sebagai berikut. 


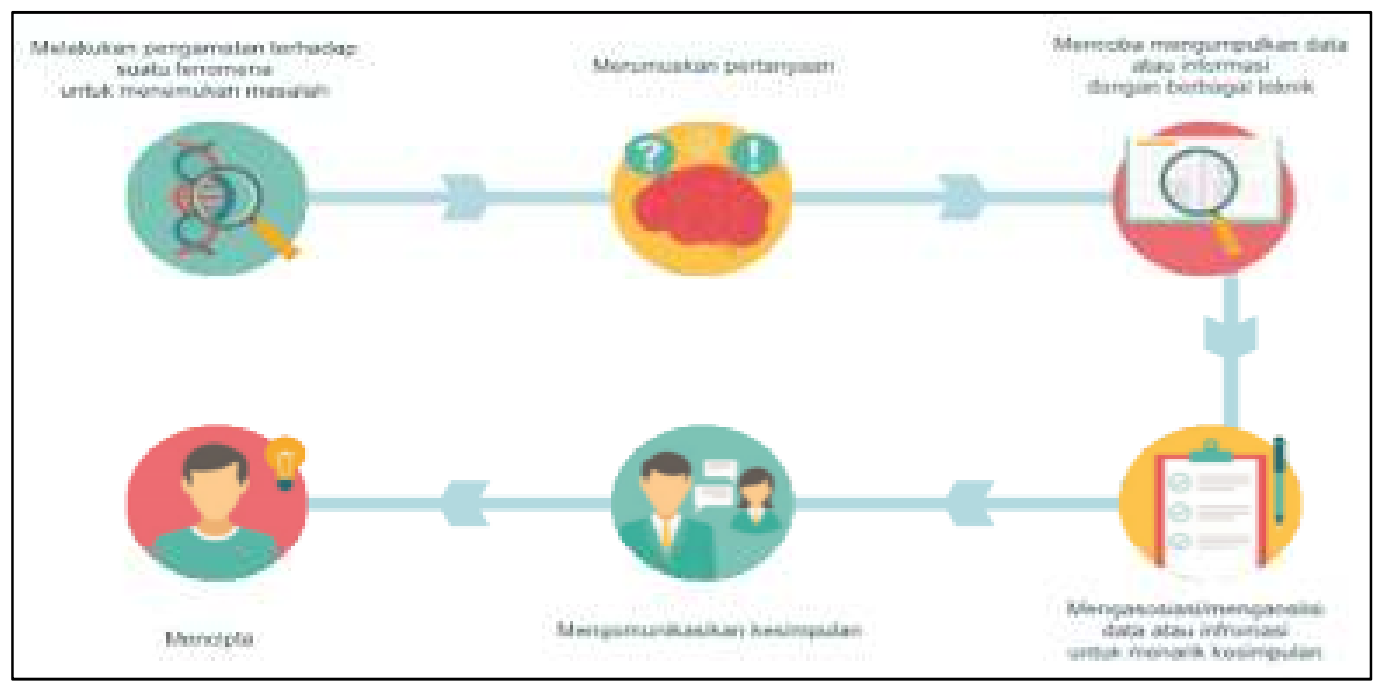

Gambar 1. Langkah - langkah pembelajaran saintifik Sumber: Kemendikbud (2016)

Pembelajaran dengan pendekatan saintifik terdiri atas lima langkah kegiatan belajar yakni mengamati (observing), menanya (questioning), mengumpulkan informasi/mencoba (experimenting), menalar atau mengasosiasi (associating), mengomunikasikan (communicating) yang dapat dilanjutkan dengan mencipta. (Kemendikbud, $2018: 39$ )

\section{a. Mengamati}

Pada tahap ini, peserta didik menggunakan panca inderanya untuk mengamati masalah atau fenomena yang diberikan guru. Hasil yang diharapkan dari langkah pembelajaran ini adalah Peserta didik menemukan masalah.

b. Menanya

Peserta didik merumuskan pertanyaan tentang apa saja yang tidak diketahui atau belum dapat lakukan terkait dengan fenomena yang diamati. Hasil kegiatan ini adalah serangkaian pertanyaan peserta didik yang relevan dengan indikator-indikator Kompetensi Dasar.

c. Mengumpulkan informasi/mencoba

Pada tahap ini, peserta didik mengumpulkan data melalui kegiatan mengamati obyek/kejadian/aktivitas dan membaca buku pelajaran. Guru menyediakan sumber-sumber belajar, lembar kerja peserta didik (LKPD), media, dan sebagainya. Guru juga membimbing dan mengarahkan peserta didik untuk mengisi lembar kerja dan menggali informasi tambahan. Hasil kegiatan ini adalah serangkaian data atau informasi yang relevan dengan pertanyaan-pertanyaan yang peserta didik rumuskan.

d. Menalar/mengasosiasi

Peserta didik menggunakan data atau informasi yang sudah dikumpulkan untuk menjawab pertanyaan-pertanyaan yang mereka rumuskan. Pada langkah ini guru mengarahkan agar peserta didik dapat menghubung-hubungkan data/informasi yang diperoleh untuk menarik kesimpulan.

e. Mengomunikasikan

Pada tahap ini, ada kelompok yang menyampaikan jawaban terhadap pertanyaan- pertanyaan mereka ke kelas secara lisan dan/atau tertulis. Sedangkan kelmpok lain mananggapi. Guru memberikan umpan balik, meluruskan, memberikan penguatan, serta memberikan penjelasan/informasi lebih luas. Guru membantu peserta didik untuk menentukan butir-butir penting dan simpulan.

(Kemendikbud, $2018: 39-40$ )

Materi pada siklus I ini adalah menemukan teorema phitagoras, triple Pythagoras, hubungan antar panjang sisi pada segitiga siku-siku sama kaki, dan hubungan antar panjang sisi pada segitiga dengan sudut: $90^{\circ}, 60^{\circ}, 30^{\circ}$. 
Kegiatan pembelajaran dengan pendekatan saitifik dapat berjalan dengan cukup baik. Pada kegiatan mengamati, peserta didik diberikan masalah konstekstual yang berkaitan dengan Pythagoras, kemudian peserta didik diberi kesempatan untuk bertanya apakah ada contoh lain dalam kehidupan sehari - hari tentang penggunaan phytagoras. Pertanyaan tersebut diberikan kepada peserta didik lain untuk menjawab dan guru menambahkan kemudian. Setelah itu, mereka berdiskusi dalam kelompok untuk mengumpulkan informasi dan mencoba menyelesaiakan
LKPD. Selanjutnya mereka mencoba menalar dalam menyelesaikan masalah pada LKPD. Setelah selesai, peserta didik diberi kesempatan menjelaskan hasil diskusi kelompoknya didepan kelas, dan kelompok yang lain menanggapi. Terakhir dengan bimbingan guru, mereka menyimpulkan materi pembelajaran pada hari itu. yaitu teorema Pythagoras dan bilangan triple pythagoras.

Adapun kegiatan - kegiatan pembelajaran tersebut dapat dilihat pada gambar-gambar berikut :

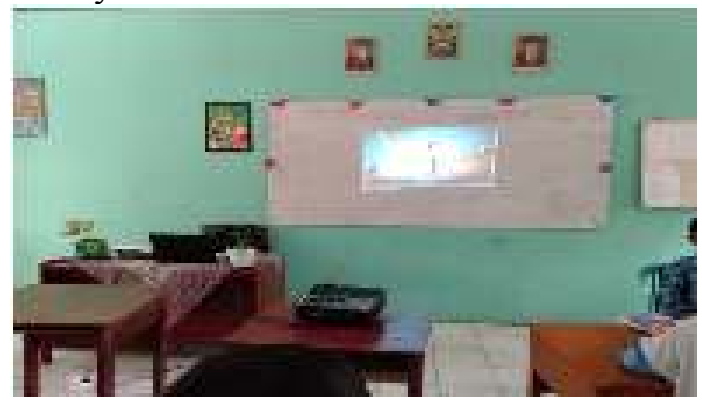

Gambar 2. Kegiatan mengamati yang dilakukan siswa

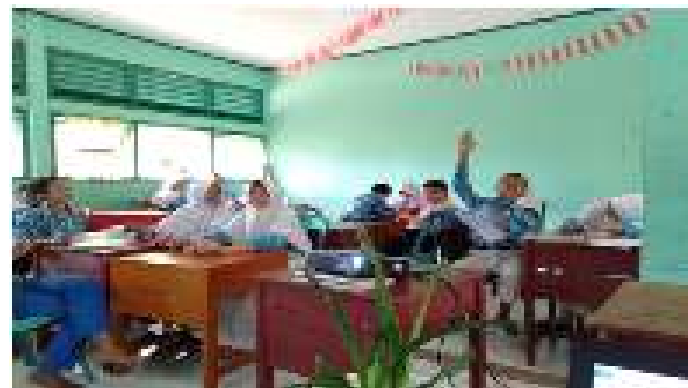

Gambar 3. Kegiatan menanya yang dilakukan peserta didik

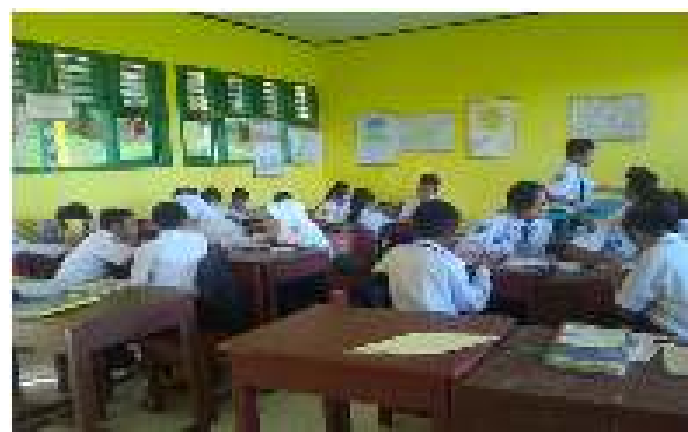

Gambar 4. Kegiatan mengumpulkan informasi / mencoba yang dilakukan peserta didik dalam diskusi kelompok 


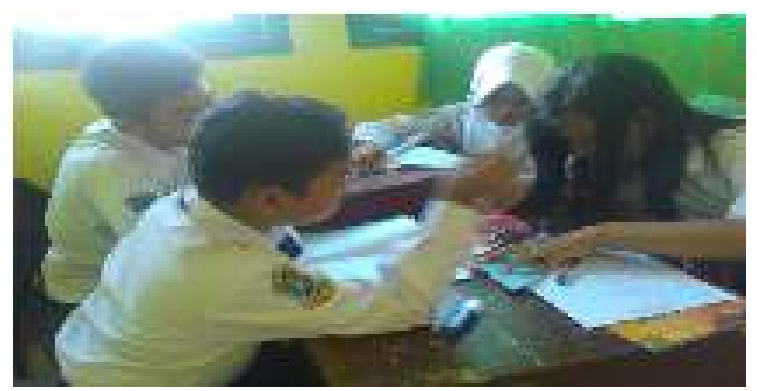

Gambar 5. Kegiatan menalar oleh peserta didik dengan bekerjasama menyelesaikan masalah yang ada pada LKPD

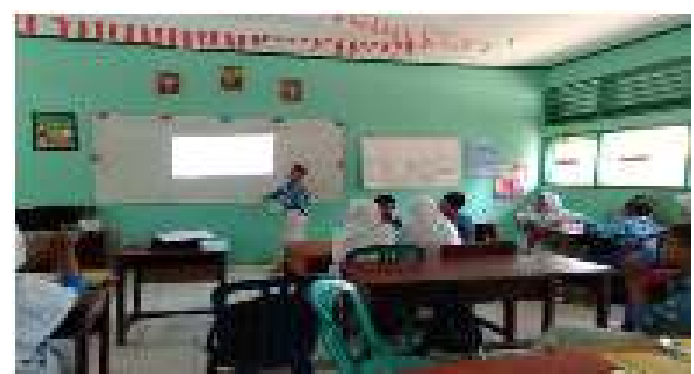

Gambar 6. Kegiatan mengkomunikasikan oleh peserta didik menjelaskan hasil kerja kelompok mereka dan kelompok lain menanggapi

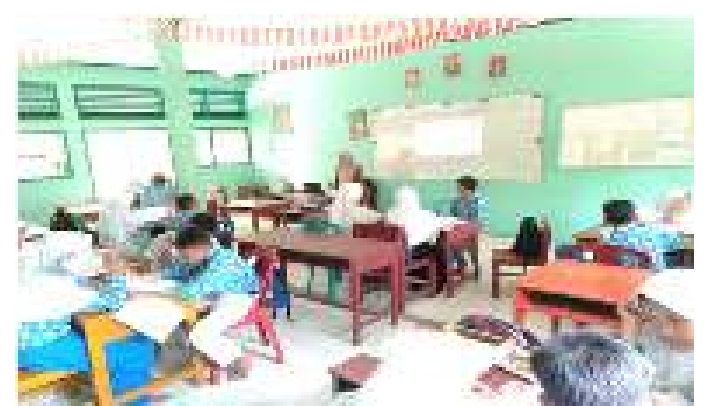

Gambar 7. Guru membimbing peserta didik untuk menyimpulkan materi yang dipelajari.

Pada akhir siklus, guru memberikan tes siklus I yaitu pada tanggal 21 Januari 2019. Berdasarkan hasil tes siklus I diperoleh nilai rata - rata peserta didik 73 dengan ketuntasan belajar klasikal $61 \%$.

Karena pada siklus I kriteria keberhasilan belum tercapai, maka dilanjutkan pada siklus II. Hal tersebut karena peserta didik masih kurang aktif dalam bertanya maupun diskusi kelompok. Sehingga pada siklus II, guru memberikan motivasi kepada peserta didik dan menyatakan bahwa keaktifan mereka dalam pembelajaran masuk dalam penilaian sikap.

Siklus II dilaksanakan dalam 3 kali pertemuan yaitu pada tanggal 28 Januari s.d 8 Februari 2019. Setelah menjelaskan tujuan pemebelajaran, guru meminta peserta didik duduk di kelompoknya masing - masing, kemudian guru melaksanakan pembelajaran sesuai dengan pendekatan saintifik seperti pada siklus I.

Materi pada siklus II adalah penerapan teorema Pythagoras pada bangun datar dan menyelesaikan masalah nyata dengan teorema Pythagoras. Setelah melakukan diskusi kelompok, secara acak ada kelompok yang mempresentasikan hasil diskusinya. Sedangkan kelompok lain menanggapi. Kemudian guru membimbing peserta didik untuk menarik kesimpulan. Pada akhir siklus, guru memberikan tes siklus II yaitu pada tanggal 5 Februari 2019. Berdasarkan hasil tes siklus II diperoleh nilai rata - rata peserta didik 79 dengan ketuntasan belajar klasikal $77 \%$. 
Berdasarkan hasil tes siklus I dan II

diperoleh data sebagai berikut :

Tabel 1. Nilai dan ketuntasan belajar peserta didik pada tes siklus I dan siklus II

\begin{tabular}{|c|l|c|c|}
\hline No & \multicolumn{1}{|c|}{ Kategori } & Tes Siklus I & Tes Siklus II \\
\hline 1. & Nilai Tertinggi & 82 & 95 \\
\hline 2. & Nilai Terendah & 58 & 70 \\
\hline 3. & Nilai Rata - rata & 73 & 79 \\
\hline 4. & Ketuntasan Belajar & $61 \%$ & $77 \%$ \\
\hline
\end{tabular}

Dari tabel 1 dapat dibuat grafik nilai dan ketuntasan belajar peserta didik pada tes siklus I dan siklus II, sebagai berikut:

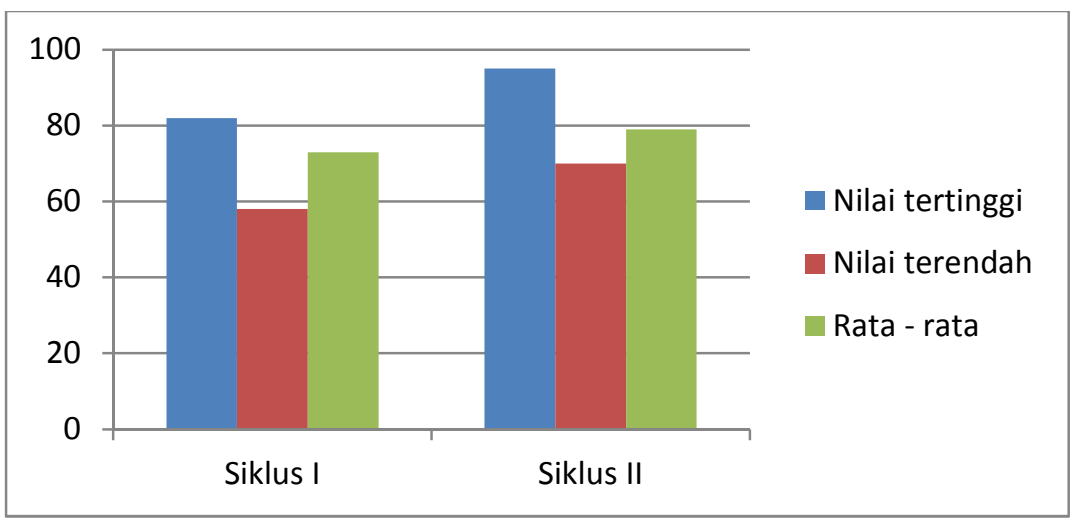

Gambar 8. Grafik nilai peserta didik pada tes siklus I dan siklus II

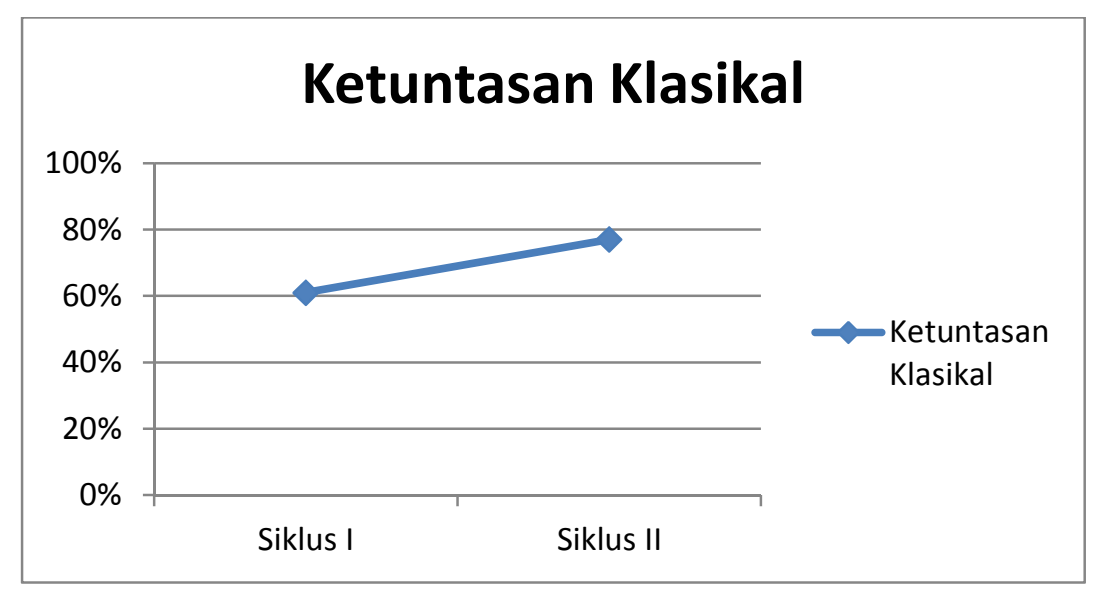

Gambar 9. Grafik ketuntasan belajar peserta didik pada siklus I dan siklus II

Data yang diperoleh dari tes siklus I diperoleh rata-rata kelas 73 dengan ketuntasan $61 \%$. Nilai rata - rata dan persentase ketuntasan tersebut belum memenuhi KKM dan persentase ketuntasan belajar klasikal yakni $75 \%$ peserta didik mendapat nilai $\geq 75$. Itu artinya kriteria keberhasilan belum tercapai, sehingga dilanjutkan pada siklus II. Hal ini dikarenakan kegiatan pembelajaran dengan pendekatan saintifik masih belum bisa berjalan secara optimal. Pada kegiatan menalar, peserta didik masih belum bisa serius.

Hasil belajar pada siklus II sudah dinyatakan tuntas karena telah mencapai standar ketuntasan belajar klasikal. Pada siklus II rata-rata kelas 79 dan ketuntasan klasikal sebesar 77\%. Pada siklus II ini, kegiatan pembelajaran dapat berjalan sesuai harapan guru karena peserta didik mulai terbiasa dengan pendekatan yang digunakan. Peserta didik sudah aktif dalam kegiatan pembelajaran. 


\section{SIMPULAN}

Hasil belajar peserta didik pada materi Teorema Pythagoras yang diajarkan dengan pendekatan saintifik mengalami peningkatan dari siklus I dan siklus II. Peserta didik juga menjadi lebih aktif dalam pembelajaran. Pendekatan saintifik merupakan kegiatan pembelajaran yang disarankan dalam kurikulum 2013. Sehingga diharapkan guru dapat menerapkannya dalam setiap kegiatan pembelajaran.

\section{REFERENSI}

Kemendikbud. 2016. Modul Pembelajaran Untuk Sekolah Menengah Pertama. Jakarta : Kemdikbud

Kemendikbud. 2017. Matematika Kelas VIII (Buku Peserta didik). Jakarta : Kemendikbud
Kemendikbud. 2018. Materi Penyegaran Instruktur Kurikulum 2013 Sekolah Menengah Pertama. Jakarta : Modul Materi Bimtek.

Lampiran Peraturan Menteri Pendidikan dan Kebudayaan Nomor 22 Tahun 2016

Saur Tampubolon. 2013. Penelitian Tindakan Kelas Sebagai Pengembangan Profesi Pendidik dan Keilmuan. Jakarta: Erlangga.

Waseso, Purbo. 2018. Kurikulum 2013 dalam Prespektif Teori Pembelajaran Konstruktivis. Jurnal studi pendidikan islam Vol.1 No.1 Januari 2018.https://media.neliti.com/media/ publications/264714-kurikulum2013-dalam-prespektif-teori-pe48cd9498.pdf 